\title{
Teachers' and School Administrators' Perception on the Strategic Leadership Practices of School Administrators
}

\author{
Yolanda D. Reyes \\ College of Education, Bataan Peninsula State University, Balanga City Bataan, Philippines
}

\begin{abstract}
How to cite this paper: Reyes, Y. D. (2018). Teachers' and School Administrators' Perception on the Strategic Leadership Practices of School Administrators. The Educational Review, USA, 2(8), 432-446. http://dx.doi.org/10.26855/er.2018.08.004
\end{abstract}

Corresponding author: Yolanda D. Reyes, Ed.D., College of Education, Bataan Peninsula State University, Balanga City Bataan, Philippines..

\begin{abstract}
This descriptive study identified how strategic leadership practices affect the management style of school administrators of teacher education institutions (TEIs) with nine selected State Universities in Central Luzon, Philippines. The study described the strategic leadership practices of school administrators in terms of Model the way, Inspire a Shared Vision, Challenge the Process, Enable Others to Act and Encourage the Heart. Based on the data gathered, it was found out the strategic leadership practices of school administrators were perceived by both as satisfactory. It was also revealed that there was significant difference between the perception of faculty members and school administrators on the leadership practices of school administrators. Enabling Others to Act' strategic leadership practice is the best predictor having the highest adjusted coefficient of determination (R2). It was recommended that the strategic leadership practices may be further improved as well as the strategic leadership to elevate the perception of teachers. Also, school administrator may capitalize on enabling others to act as strategic leadership practice since it has been found out that it is the best predictor.
\end{abstract}

\section{Keywords}

Teachers' and School Administrators' Perception, Strategic Leadership Practices, School Administrators

\section{Introduction}

The roles of school heads and administrators as institutional leaders are very vital for the academe's sustainability. Their leadership skills, characteristics, and styles as leaders are important ingredients for an academic institution's stability and development. As such, it has become a standard practice in the school that leaders are expected to possess characteristics which create harmonious relationship, foster innovation, provide support for continuous learning with teachers, and meet achievement goals. However, the nature of leadership styles of the school administrators is complex and is influenced by both personal and social conditions. Marzano et al. (2005) opined that leadership styles of school administrators are influenced by several extraneous factors and that effective leadership influences the development of productive social and cultural climate or structures in schools. Schools which are over managed and badly led by school leaders tend to lose any sense of sprit or purpose.

On the other hand, academe with strong charismatic leaders but are poor school managers may improve temporarily but will eventually fail. Hence, it takes both charisma and good leadership skills to successfully operate a school and manage students and personnel. As such, the challenges of modern school organizations require the objective perspective of the school manag- 
ers as well as the well-defined vision and commitment implicated by a specific leadership style.

In the Philippines, state universities and colleges are beset with bureaucratic problems that call for strong school leadership. The challenge is set on the school managers to meet standards to produce results without imposing demands on their subordinates. This is actually reflective of the thrusts of the national government through the Commission on Higher Education (CHED) which calls for quality school management vis-a-vis the changing school climate or conditions. As such, increased attention to the quality of school leadership in higher education has become a policy trend. Hence, there is a daunting task for school leaders to face.

The decentralization of universities and colleges created new challenges for the school administrators particularly on the leadership traits that they need to model on in gearing the school towards quality school management. They are increasingly expected to create a climate that is conducive to teaching and learning and that support and supervise teachers' work in classroom management and the use of the curriculum and its localization. They are also asked to innovate and promote development in the school which may lead towards improving student performance and accountability.

Hence, this study ventured on the leadership and management characteristics of school administrators of teacher education institutions. The problem is brought by the compliance to the Education for All goals (EFA) and the domino effect of these changes to the school administrators as leaders of the academic communities. In this notion, school leadership becomes one of the most critical elements in enhancing organizational performance. In the era of challenged leadership, school administrators in the Philippines take the helm in the development and execution of strategic organizational decisions to inspire teachers and bring them along the competitive edge in the best interest of stakeholders - the students and the community.

\section{Statement of the Problem}

The general problem of the study is: "How strategic leadership practices affect the management style of school administrators of teacher education institutions (TEIs) in Region III during the Academic Year 2014-2015?"

Specifically, it sought answers to the following questions:

1) How may the strategic leadership practices of school administrators in selected SUCs be described as perceived by faculty members and school administrators in terms of :

a. Model the Way;

b. Inspire a Shared Vision;

c. Challenge the Process;

d. Enable Others to Act and

e. Encourage the Heart?

2) Is there any significant difference in the perceptions of school administrators and their subordinates regarding the formers' strategic leadership practices?

\section{Methods}

\subsection{Methods and Techniques of the Study}

This study which aimed to identify how strategic leadership practices affect the management style of school administrators of teacher education institutions (TEIs) in Region III during the Academic Year 2014-2015 utilized the descriptive type of research. As exemplified by Viscarra (2003), this type of research involves the purposive process of gathering, analyzing, classifying, and tabulating data about prevailing conditions, practices, processes, trends, and cause and effect relationships and then asking adequate and accurate interpretation about such data with or without the aid of statistic method. 
On the other hand, Galero-Tejero (2011) mentioned that descriptive research as a purposive process of gathering data makes it possible for the prediction of the future on the basis of the reaction of the respondents towards certain issues. The researcher can be able to assess, evaluate and interpret the needed information from the respondents through the questionnaire given and answered by the respondents. In descriptive design, the study focuses at the present condition. These are valuable in providing facts on which scientific judgments may be based.

\subsection{Research Instruments}

The primary research instrument that the researcher used is the survey-questionnaire of which three sets were prepared - one each for faculty members, deans and academic/program coordinators.

Each set of survey-questionnaire was divided into three. Part I dealt with the strategic leadership practices of school administrators in terms of Model the Way, Inspire a Shared Vision, Challenge the Process, Enable Others to Act and Encourage the Heart. Finally, Part II explored the innovative management of school administrators in terms of innovative vision and strategy, resources, organization structure, culture and climate and innovation process.

In evaluating the strategic leadership practices of school administrators in terms of Model the Way, Inspire a Shared Vision, Challenge the Process, Enable Others to Act and Encourage the Heart, the following Likert Scale (Figure 1) were used:

\begin{tabular}{|c|c|c|c|}
\hline Scale & Descriptive Rating & & Indicators \\
\hline 5 & - Always & $\mathrm{A}$ & $\begin{array}{l}\text { The item/event happens at all times } \\
\text { or } 100 \% \text { of the time. }\end{array}$ \\
\hline 4 & - Fairly Often & FO & $\begin{array}{l}\text { - The item/event happens many times } \\
\text { or } 67 \%-99 \% \text { of the time. }\end{array}$ \\
\hline 3 & - Sometimes & $\mathrm{S}$ & $\begin{array}{l}\text { The item/event happens every now } \\
\text { and then or } 33 \%-66 \% \text { of the time. }\end{array}$ \\
\hline 2 & - Once in a While & 0 & $\begin{array}{l}\text { The item/event happens every now } \\
\text { and then or } 1 \%-32 \% \text { of the time. }\end{array}$ \\
\hline 1 & - Rarely & $\mathrm{R}$ & $\begin{array}{l}\text { - The item/event does not happen at all } \\
\text { times or } 0 \% \text { of the time. }\end{array}$ \\
\hline
\end{tabular}

Figure 1. Likert scale.

\subsection{Construction and Validation of the Instrument}

The adapted survey-questionnaire that was used in the study: the Leadership Practices Inventory of Kouzes and Posner (1993).The Leadership Practices Inventory of Kouzes and Posner (1993) were designed to measure strategic leadership qualities. It is a 50-item Likert-scale questionnaire measuring the five areas of challenging the process, inspiring a shared vision, enabling others to act, modeling the way, and encouraging the heart. A higher value represented greater use of a leadership behavior. It has been shown to have high face validity and predictive validity, meaning that the results not only make sense to people, but also predict whether a leader's performance is high, moderate, or low.

The instrument was slightly modified to suit and reflect the needs of the academic institutions that the present research caters. The modified instrument was presented to the experts in the field of educational management from the different academic institutions in Bataan Peninsula State University and Tomas del Rosario College for approval. Likewise, the questionnaire underwent validation through a pre-trial survey to establish validity and reliability. Reliability of the tool was conducted through the SPSS with .95 as its Cronbach's alpha value. 


\subsection{Data Gathering Procedures}

As a standard operating procedure, the researcher secured an endorsement letter and permission to proceed with the study from the Dean of the Graduate School of BPSU. These letters were forwarded to the President of various SUCs included in the study asking for permission to begin the process of data gathering. Upon receiving permission from the SUCs involved, the researcher started gathering the data needed to complete the study. SUCs which are farthest from the place of origin of the researcher were prioritized. A month was allotted for the distribution and retrieval of the survey-questionnaire. At the end of the month, only $90 \%$ of the questionnaire was retrieved due to some leave of absence of the respondents.

The data gathered by the researcher were carefully recorded and tallied using a tabular form which she personally prepared with the advice of the statistician.

\subsection{Statistical Treatment of Data}

The data obtained were encoded and statistically processed with the use of PASW Statistics version 18 (previously known as SPSS). Statistical tests such as mean, standard deviation, t-test, correlation and stepwise regression analysis were employed to find answers to the specific questions raised in the Statement of the Problem in Chapter I of this study.

Weighted mean was utilized to find out the strategic leadership practices of school administrators as perceived by faculty members and themselves. Independent Samples T-test was used to determine if there is any significant difference in the perceptions of school administrators and their subordinates regarding the formers' strategic leadership practices. Levene's test was employed prior to conducting T-test to ensure that the assumption of equality of variances is met and to avoid erroneous results.

On the other hand, with the aid of PASW Statistics Version 18, the probability values (p-values) of significance level of statistical tests are readily available for comparison with a 0.05 level of significance which was set by the researcher prior to the conduct of the study. If the p-value is less than or equal to 0.05 , the statistical test is significant and therefore the null hypothesis is rejected. Otherwise, it is not rejected.

\section{Results}

Table 1 shows the strategic leadership practices of school administrator, strategic leadership practices of school administrators in selected SUCs as perceived by the faculty members with respect to Model the Way.

As gleaned from Table 1, administrators and faculty members, on the average, reported that the indicators are fairly often observed. Overall, the respondents are satisfied with the 'modelling the way' leadership practices of school administrators. The administrators, themselves provided a composite mean of 4.26 while the faculty members with 3.93 indicating that they are satisfied with their administrators' strategic leadership practices in terms of "modelling the way" for their subordinates. It means that the school administrators, to some extent, were able to create a program of excellence and then set the example for other SUCs to follow. This excellence in transforming the school through good leadership was guided by high standards by which school is measured.

It means that school administrators and teachers both passionately believe that the former can make a difference by envisioning a good future for the organization, its personnel and the clients it served by creating an ideal and unique image of the TEIs. Technically, school administrators are guided by the mission and vision of the school and are also laboring to attain the institutional goals set by the TEIs.

These aspects alone form a big chunk of the vision of the school which challenges them to make a difference. Lazaro (2011) noted that this is what drives most school leaders to introduce changes in the school program or operations. According to Abu-Tineh et al (2009), inspiring a shared vision is vital for bringing people in any organization together to foster a commit- 
ment to a shared future they seek to create. This is practiced by the school administrators in the TEIs in many ways they can imagine. For the administrators, their highest mean rating of 4.36 is on 'showing others how their long-term interests can be realized by enlisting in a common vision'. This is evident by the presence of long and medium term development plan which are being crafted by each TEI depending on the needs of the teachers, the institution and the students. The program of work that is encapsulated in the plan is being guided by the mission as well as the vision of the university.

It has to be this way since vision creates a fundamental sense of purpose and guide the activities of a school over a number of years (Matthews and Sammons, 2005). Visioning is imperative to the establishment of the direction of the TEIs, but goals must also be set to achieve this school vision. In order to be successful in leading the school organization towards its goals, school leaders must create a vision that can be followed by all its people.

Table 1. Model the way strategic leadership practices of school administrators.

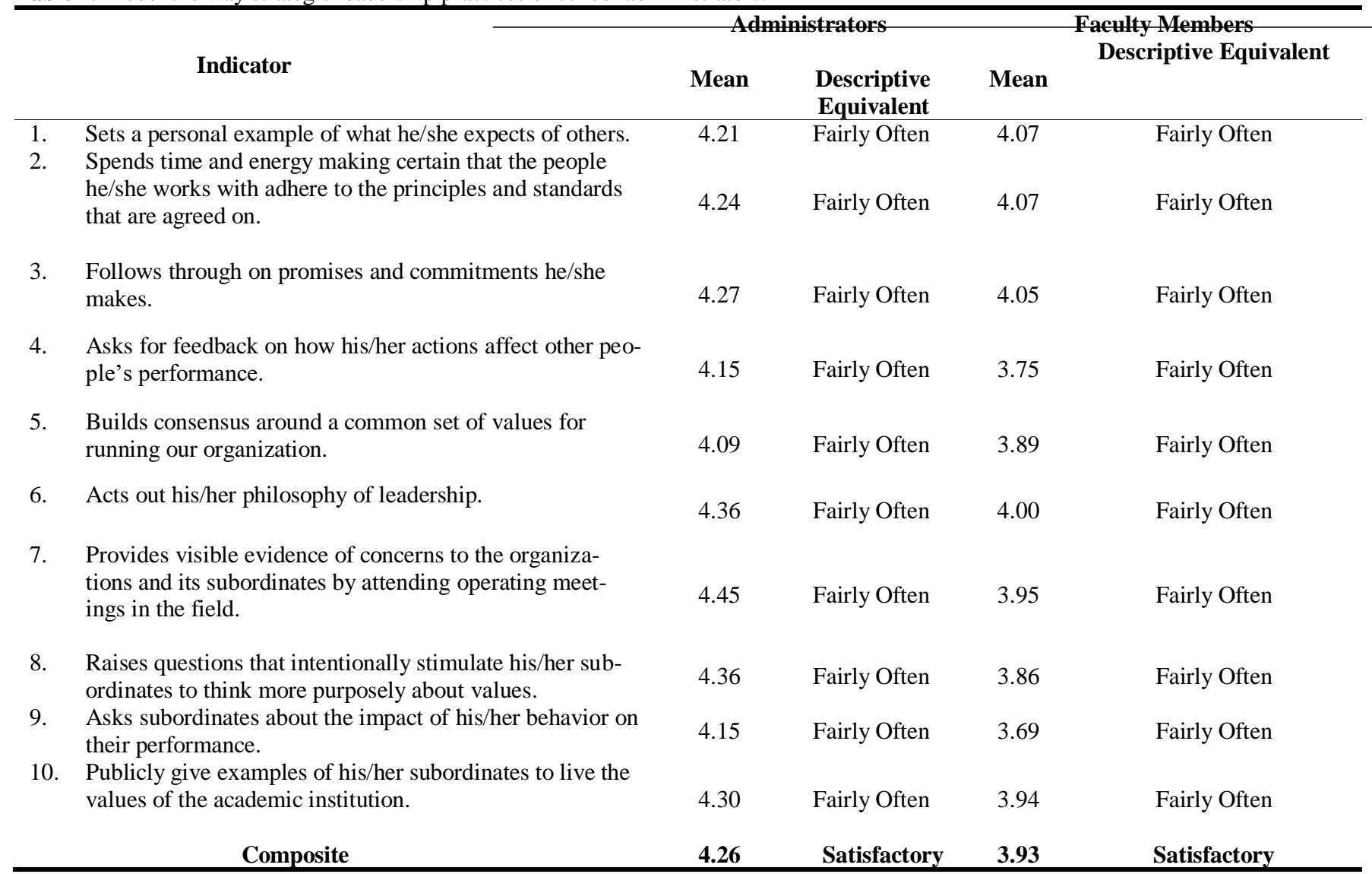

For the faculty members, they are most satisfied with the administrators' "talking about future trends that will influence how their work gets done" with the highest mean of 4.01. This is followed by "describing a compelling image of what our future could be like" with mean of 3.89. Hence, the faculty members think that their school administrators are futuristic and visionaries which provides the direction to which the academe should go to and the personnel and students should become and as DeLucia (2011) states that they envision what could be. Thus, it is the practice of most TEIs to study future trends and emerging issues in school leadership and management by participating in seminars and trainings that are sponsored by stemmed professional organizations. They are also members of professional organizations that involve deans and heads of school offices like Council of Deans of Colleges of Education (CDCE) and State Universities and Colleges of Teacher Education Association 
(SUCTEA) which provide them the latest trends and issues that encompass management of higher education institutions (HEIs) and TEIs. Meanwhile, it can be surmised that both faculty members and administrators themselves placed 'using clever, meaningful metaphors that can touch people, inspire their imagination and make them feel part of the special team' as one of the areas of weaknesses of administrators with respect to inspiring shared vision strategic leadership practices. School administrators' lowest mean rating of 4.12 is on 'demonstrating concerns on their needs' and then on "using clever, meaningful metaphors that can touch people, inspire their imagination and make them feel part of the special team" with mean of 4.15 . In terms of weaknesses on inspiring shared vision, the faculty deemed that "using clever, meaningful metaphors that can touch people, inspire their imagination and make them feel part of the special team" needs to be enhanced having the lowest mean of 3.71. It means that school administrators are straightforward in communicating with their people.

Table 2 displays the strategic leadership practices of school administrators in selected SUCs as perceived by faculty members and themselves with respect to 'Inspiring a Shared Vision'.

Noticeably, the respondents perceived that the indicators of administrators strategic leadership practices in terms of "inspiring a shared vision" are fairly often observed. As a whole, the administrators rated themselves with a satisfactory rating of 4.22 . Also, the faculty members considered the administrators' "inspiring a shared vision" practices to be satisfactory having a composite mean of 3.86 .

Table 2. Inspiring a shared vision' strategic leadership practices of school administrators.

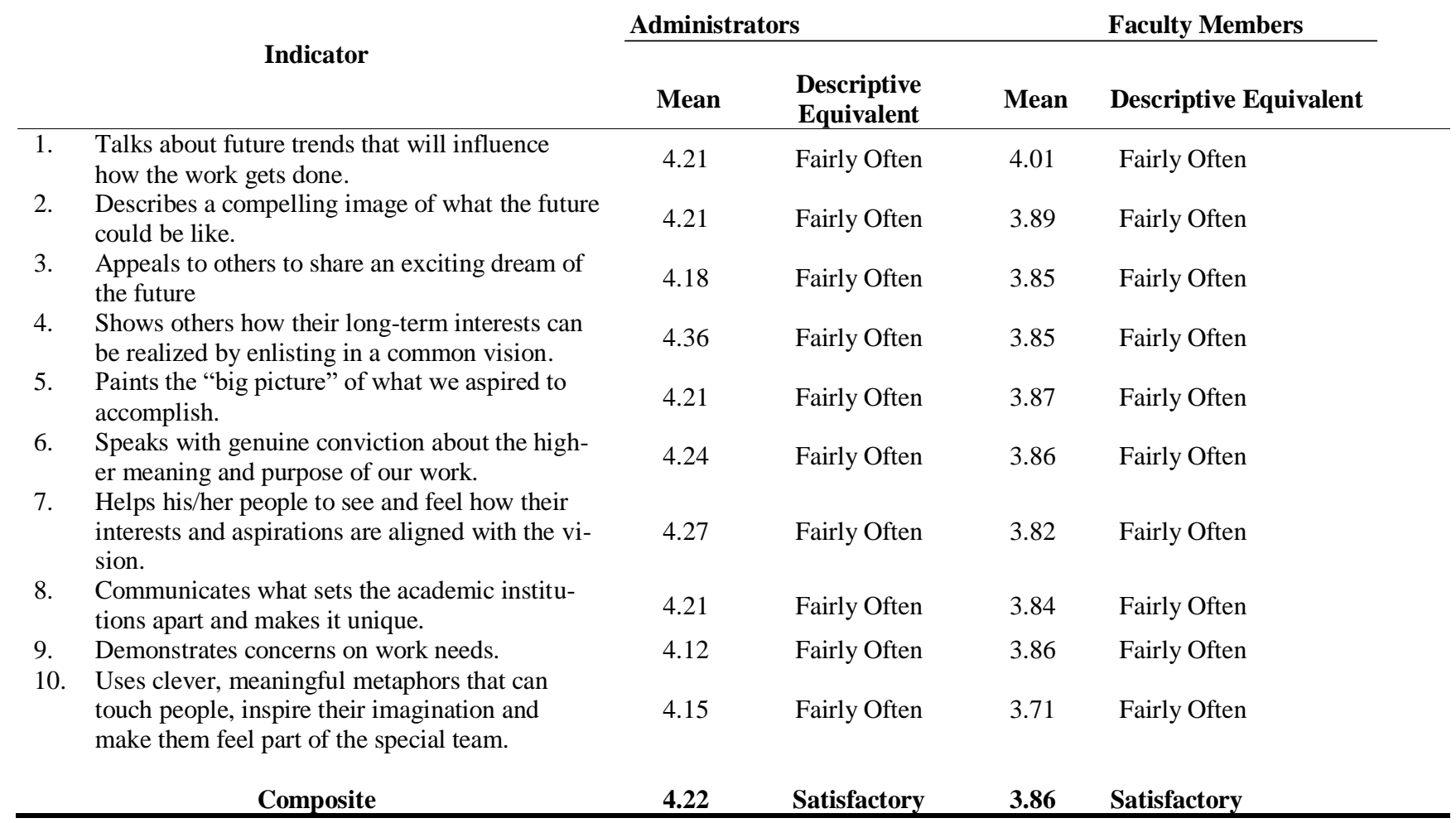

It means that school administrators and teachers both passionately believe that the former can make a difference by envisioning a good future for the organization, its personnel and the clients it served by creating an ideal and unique image of the TEIs. Technically, school administrators are guided by the mission and vision of the school and are also laboring to attain the institutional goals set by the TEIs. 
These aspects alone form a big chunk of the vision of the school which challenge them to make a difference. Lazaro (2011) noted that this is what drives most school leaders to introduce changes in the school program or operations. According to Abu-Tineh et al (2009), inspiring a shared vision is vital for bringing people in any organization together to foster a commitment to a shared future they seek to create. This is a job of a school leader is which created a fundamental sense of purpose and guide the activities of a school over a number of years. For the administrators, their highest mean rating of 4.36 is on 'showing others how their long-term interests can be realized by enlisting in a common vision'. This is evident by the presence of long and medium term development plan which are being crafted by each TEI depending on the the needs of the teachers, the institution and the students. The program of work that is encapsulated in the plan is being guided by the mission as well as the vision of the university.

It has to be this way since vision creates a fundamental sense of purpose and guide the activities of a school over a number of years (Matthews and Sammons, 2005). Visioning is imperative to the establishment of the direction of the TEIs, but goals must also be set to achieve this school vision. In order to be successful in leading the school organization towards its goals, school leaders must create a vision that can be followed by all its people.

Table 3 reflects the strategic leadership practices of school administrators in selected SUCs as perceived by faculty members and themselves with respect to "Challenge the Process".

Table 3. Challenge the process' strategic leadership practices of school administrators.

\begin{tabular}{|c|c|c|c|c|c|}
\hline \multirow{2}{*}{\multicolumn{2}{|c|}{ Indicator }} & \multicolumn{2}{|c|}{ Administrators } & \multicolumn{2}{|c|}{ Faculty Members } \\
\hline & & Mean & $\begin{array}{l}\text { Descriptive } \\
\text { Equivalent }\end{array}$ & Mean & $\begin{array}{l}\text { Descriptive } \\
\text { Equivalent }\end{array}$ \\
\hline 1. & $\begin{array}{l}\text { Seeks out challenging opportunities that test } \\
\text { his/her own skills and abilities. }\end{array}$ & 4.12 & Fairly Often & 3.83 & Fairly Often \\
\hline 2. & $\begin{array}{l}\text { Challenges subordinates to try out new and } \\
\text { innovative ways to do their work. }\end{array}$ & 4.03 & Fairly Often & 3.78 & Fairly Often \\
\hline 3. & $\begin{array}{l}\text { Searches outside the formal boundaries of } \\
\text { his/her organization for innovative ways to im- } \\
\text { prove what we do. }\end{array}$ & 4.12 & Fairly Often & 3.76 & Fairly Often \\
\hline 4. & $\begin{array}{l}\text { Asks "What can we learn?" when things don't } \\
\text { go as expected. }\end{array}$ & 4.21 & Fairly Often & 3.67 & Fairly Often \\
\hline 5. & $\begin{array}{l}\text { Makes certain that we set achievable goals, } \\
\text { make concrete plans, and establish measurable } \\
\text { milestones for the projects and programs we } \\
\text { work on. }\end{array}$ & 4.12 & Fairly Often & 3.80 & Fairly Often \\
\hline 6. & $\begin{array}{l}\text { Experiments and takes risks, even when there is } \\
\text { a chance of failure. }\end{array}$ & 4.03 & Fairly Often & 3.75 & Fairly Often \\
\hline 7. & $\begin{array}{l}\text { Introduces new ideas, solutions and methods } \\
\text { into use. }\end{array}$ & 4.18 & Fairly Often & 3.75 & Fairly Often \\
\hline 8. & $\begin{array}{l}\text { Fosters a "can-do attitude" by providing oppor- } \\
\text { tunities for people to gain mastery over tasks } \\
\text { one step at a time. }\end{array}$ & 4.18 & Fairly Often & 3.78 & Fairly Often \\
\hline 9. & $\begin{array}{l}\text { Gives people meaningful works and meaningful } \\
\text { rewards which lead to meaningful action in } \\
\text { pursuit of new opportunities. }\end{array}$ & 4.03 & Fairly Often & 3.76 & Fairly Often \\
\hline 10. & $\begin{array}{l}\text { Allows the free flow of ideas from the outside } \\
\text { and remains open to opinion other than his/her } \\
\text { own. }\end{array}$ & 4.12 & Fairly Often & 3.74 & Fairly Often \\
\hline & Composite & 4.12 & Satisfactory & 3.76 & Satisfactory \\
\hline
\end{tabular}

With respect to challenging the process, the respondents deemed that the indicators are all fairly often practiced by the school administrators. Generally, the administrators themselves considered their strategic leadership practices in terms of challenging the process to be satisfactory having a composite mean of 4.12 . 
Though with relatively lower rating, faculty members conformed as indicated by their composite mean of 3.76. In a way, the school administrators of the TEIs under study are willing to challenge the system in order to turn these ideas into actions and to get new products, processes, and services adopted. To improve the organization, they seek out challenging opportunities that test their skills and abilities and look for innovative ways. In subscribing to this notion, school leaders are actually challenging and changing the status quo by experimenting and taking risks with new approach. As mentioned by Abu-Tineh et al. (2009), challenging the process is a way of life for strategic leaders which can be done by creating new ideas or recognizing and supporting new ideas. These are reflective of the practices of the school administrators.

To challenge the process, school administrators of the TEIs subject the institutions to accreditation processes like that of AACCUP. This is done to determine whether the present practices of the TEIs are still valuable and necessary today or at the moment or have become absolute due to emerging trends and issues in managing and leading TEIs. Another best practice of the TEIs to challenge the process is benchmarking to other TEIs to compare notes and in the process adopt new practices and policies that will best serve the needs of the school, the faculty members and the students. These practices are reflective of the efforts of the school administrators to change, improve and take risks by branching out and trying new and innovative approaches in order to foster improvement. Northpuse (2010) noted that challenging the process means being willing to take risks to change the status quo, embrace innovation, learn, and grow. It only goes to show that whatever opportunities that show up along the way, school leaders should be bound to take that since change means growth for the academe and its people.

In particular, the administrators are most satisfied with asking "What can be learned when things don't go as expected" having the highest mean rating of 4.21, which is the lowest mean for teachers and then with "introducing new ideas, solutions and methods into use" and fostering a "can-do attitude" by providing opportunities for people to gain mastery over tasks one step at a time' with mean of 4.18. This situation reflects the attitude of the school administrators as risk taker and innovative by experimenting on ideas and processes. It echoes Northpuse (2010) who pointed out that challenging the process means being willing to take risks to change the status quo, embrace innovation, learn, and grow. School leaders are risks-takers and thus, experimenting on new ideas by transcending towards the outside of the academe which serve as the external stakeholders of the university. The risks that they take are to actually promote innovation and new ways to do things in school operation or programs. These outsourcing of external ideas from other stakeholders are used to better structure, culture, and outcomes. They build commitment of constituents through reward, encouragement, and task delegation. Leaders learn from their mistakes, and build upon past failures in order to make something happen.

For the faculty members, their highest mean rating of 3.85 is on "seeking out challenging opportunities that test his/her own skills and abilities". This is followed by making certain that the achievable goals, makes concrete plans, and establish measurable milestones for the projects and programs we worked on' with mean of 3.80. It only goes to show that whatever opportunities that show up along the way, the teachers believe that school leaders should be bound to take that since change means growth for the academe and its people. Hence, the teachers and the school administrators in the TEIs under study are united in stating that the latter are innovative-minded leaders and risk-takers to get new products, processes, services, and systems adopted. These attitudes of the school leaders are reflective of the learning organizations that Senge (2006) proposed where people continually expand their capacity to create the results they truly desire, where new and expansive patterns of thinking are nurtured, where collective aspiration is set free, and where people are continually learning how to learn together.

Meanwhile, the lowest mean rating of 4.03 for school administrators are on challenging subordinates to try out new and innovative ways to do their work, "experimenting and taking risks, even when there is a chance of failure", and "giving people meaningful works and meaningful rewards which lead to meaningful action in pursuit of new opportunities". On the other hand, teachers' lowest mean rating of 3.67 is on "asking 'What can we learn?' when things don't go as expected" which is the highest mean for the administrators. Moreover, this lowest mean rating is followed by 3.74 which is on "allowing free flow of ideas 
from the outside and remains open to opinion other than his/her own" and then 3.75 obtained by both "experimenting and taking risks, even when there is a chance of failure" and "introducing new ideas, solutions and methods into use".

It can be deduced from the findings that the lowest mean statement for school administrators and teachers are complimentary by nature. While some teachers believe that learning through the hard way can be tricky for the school administrators, some of the school leaders do not want to challenge the teachers since it may send a wrong signal to teachers that they are being challenged since perhaps, they are threat to the position. Dalton (2005) explains that school leaders must recognize and support idea development. To challenge the teachers is a test of threshold for school administrators.

Table 4. Enabling others to act' strategic leadership practices of school administrators.

\section{Indicator}

1. Develops cooperative relationships among the people he/she works with.

2. Actively listens to diverse points of view.

3. Treats others with dignity and respect.

4. Supports the decisions that people make on their own.

5. Gives people a great deal of freedom and choice in deciding how to do their work.

6. Ensures that people grow in their jobs by learning new skills and developing themselves.

7. Helps create a trusting climate which fosters mutual respect that helps sustain extraordinary efforts.

8. Provides people on the front line proper vision and training and follow that up with responsibility, information, and more training so they could act on decisions.

9. Encourages others to share resources and information.

10. Consults concerned people during decision-making process.

\section{Administrators \\ Mean}

4.18

4.25

4.18

4.15

4.15

4.15

4.03

Fairly Often

\begin{tabular}{llll}
4.03 & Fairly Often & 3.76 & Fairly Often \\
& & & \\
4.09 & Fairly Often & 3.80 & Fairly Often \\
4.18 & Fairly Often & 3.76 & Fairly Often \\
$\mathbf{4 . 1 4}$ & Satisfactory & $\mathbf{3 . 8 3}$ & Satisfactory \\
\hline
\end{tabular}

3.79

Fairly Often

Faculty Members

Mean Descriptive Equivalent

$3.83 \quad$ Fairly Often

3.87 Fairly Often

Fairly Often

Fairly Often

Fairly Often

Fairly Often

Table 4 reveals the strategic leadership practices of school administrators in selected SUCs as perceived by faculty members and themselves with respect to "Enabling Others to Act".

With respect to "enabling others to act" as part of strategic leadership practices, respondents reported that the indicators are fairly often observed among the school administrators. Particularly, the administrators rated "actively listening to diverse points of view" with the highest mean of 4.25. This is followed by "developing cooperative relationships among the people he/she works with", "treating others with dignity and respect", and "consulting concerned people during decision-making process"; all with mean of 4.18. The findings implied that school administrators are involved in planning and give teachers the freedom of choice in the decision-making. In doing so, the school leaders are allowing the teachers to do their job and to realize their full potential. This act of enabling others fosters collaboration and empowerment according to Abu-Tineh et al. (2009). Such actuations may pave the way for the creation of an atmosphere of trust and human dignity which help each person feel 
capable and powerful. Leaders consider the needs and interests of others and let them feel as if they carry ownership and responsibility in the organization.

For the faculty members, they are most pleased with how the administrators treat others with dignity and respect having the highest mean rating of 3.88. This is followed by "actively listens to diverse points of view" and giving people a great deal of freedom and choice in deciding how to do their work' with means of 3.87.

It is implied in the findings that the school leaders maintains an open discussion of plans and programs among the members of the academic community and that open communication system is maintained. Since the faculty members are encouraged to participate actively in the affairs of the school, it is a sign that the school administrators are considering them as integral part of the organization which is a way of upholding their dignity and respecting their existence. In the process, trust among the teachers is developed and harnessed. According to Saban and Wolfe (2009), the ability of school leaders to become instrumental in the development of trusting relationships and focusing on gains is a reflection of a good school administrator. This can be observed in various coordinated work assigned to faculty members like Field Study, Research and Community Extension Service where they are given the freedom to decide on the manner they will stir the TEI, guided by the vision and mission of the college and university.

On the other hand, the administrators are least satisfied with "helping create a trusting climate which fosters mutual respect that helps sustain extraordinary efforts" and "providing people on the front line proper vision and training and follow that up with responsibility, information, and more training so they could act on decisions" having the lowest mean rating of 4.03. Meanwhile, with respect to weaknesses, the faculty members deemed that the administrators are lowest in terms of "providing people on the front line proper vision and training and follow that up with responsibility, information, and more training so they could act on decisions' having the lowest mean of 3.76. The next lowest mean rating of 3.79 is on "helping create a trusting climate which fosters mutual respect that helps sustain extraordinary efforts".

It can be deduced from the findings that perhaps, in some instances where the work is so critical and there is no faculty member that is academically qualified enough to take on the tasks, the school administrators lack the choices to fill the gap. This connotes the claim of Kouzes and Posner (2005) who revealed that some people lack the skills to demonstrate their beliefs. As such, the findings implied that leaders must provide the resources and training that is needed to successfully complete a task or assignment making individuals feel more capable and increasing effectiveness (Wiley and Sons, 2011). This is brought by the fact that people are strengthened if school leaders will share with them power and information.

Table 5 presents the strategic leadership practices of school administrators in selected SUCs as perceived by faculty members and themselves in terms of "Encouraging the Heart".

As shown in Table 5, both the administrators and faculty members are satisfied with the said aspect of strategic leadership having composite means of 4.09 and 3.81, respectively. Hence, it can be noted that the school administrators have the genuine heartfelt concern and care for their teachers which is, according to Kouzes and Posner (2011) is a true measure of encouraging the heart. Among the TEIs, personnel and students are continuously encouraged and motivated by the school administrators so that they will be able to partake or contribute in the achievement of the school organization's goals. Ideally, teachers want to be recognized as human beings and leaders need to pay attention to the little things, taking time to ask questions.

With regards to 'encouraging the heart' component of strategic leadership practices, respondents perceived that the indicators are fairly often observed amongst the school administrators. To encourage the heart of the teachers, school administrators must celebrate the achievements together which is a way of sending a strong message to the members that they are part of the group and part of something significant. Hence, school administrators find time to celebrate individual or group achievements because they are the most prominent personality in the organization and serve as a role model. 
Table 5. Encouraging the heart' strategic leadership practices of school administrators.

\begin{tabular}{|c|c|c|c|c|}
\hline \multirow[b]{2}{*}{ Indicator } & \multicolumn{2}{|r|}{ Administrators } & \multicolumn{2}{|r|}{ Faculty Members } \\
\hline & Mean & $\begin{array}{l}\text { Descriptive Equiv- } \\
\text { alent }\end{array}$ & Mean & Descriptive Equivalent \\
\hline $\begin{array}{l}\text { 1. Develops cooperative relationships among the people } \\
\text { he/she works with. }\end{array}$ & 4.18 & Fairly Often & 3.83 & Fairly Often \\
\hline 2. Actively listens to diverse points of view. & 4.25 & Fairly Often & 3.87 & Fairly Often \\
\hline 3. Treats others with dignity and respect. & 4.18 & Fairly Often & 3.88 & Fairly Often \\
\hline 4. Supports the decisions that people make on their own. & 4.15 & Fairly Often & 3.83 & Fairly Often \\
\hline $\begin{array}{l}\text { 5. Gives people a great deal of freedom and choice in } \\
\text { deciding how to do their work. }\end{array}$ & 4.15 & Fairly Often & 3.87 & Fairly Often \\
\hline $\begin{array}{l}\text { 6. Ensures that people grow in their jobs by learning } \\
\text { new skills and developing themselves. }\end{array}$ & 4.15 & Fairly Often & 3.85 & Fairly Often \\
\hline $\begin{array}{l}\text { 7. Helps create a trusting climate which fosters mutual } \\
\text { respect that helps sustain extraordinary efforts. }\end{array}$ & 4.03 & Fairly Often & 3.79 & Fairly Often \\
\hline $\begin{array}{l}\text { 8. Provides people on the front line proper vision and } \\
\text { training and follow that up with responsibility and train- } \\
\text { ings. }\end{array}$ & 4.03 & Fairly Often & 3.76 & Fairly Often \\
\hline 9. Encourages others to share resources and information. & 4.09 & Fairly Often & 3.80 & Fairly Often \\
\hline $\begin{array}{l}\text { 10. Consults concerned people during decision-making } \\
\text { process. }\end{array}$ & 4.18 & Fairly Often & 3.76 & Fairly Often \\
\hline Composite & 4.14 & Satisfactory & 3.83 & Satisfactory \\
\hline
\end{tabular}

This is reflective of the highest mean given by the school administrators and teachers to the statement - praising concerned people for a job well done" with mean of 4.27 and 3.93, respectively. It echoes Puccio et al. (2006) who noted that school leaders must encourage the school employees and students towards completing the tasks or any delegated duties and responsibilities among them. Good school leaders recognize and reward their members for their accomplishments by showing appreciation and giving praise for the work and contributions of the members. Among the TEIs, teachers are given recognitions through Program on Awards and Incentives for Service Excellence (PRAISE), best performing faculty members and the likes. These recognitions, according to Mulford (2008), are sources of a greater collective identity and community spirit among faculty members.

Thus, the findings implied that encouragement should start from school leaders which means that they have to show to the members that they are modelling what should be done and how one should act inside the organization. They must spend quality time and attention for its members by socializing with them, involving in a small chat most frequently and paying attention to small gains and praising the efforts exerted by the members. Effective leaders create rituals and symbols that celebrate wins, reinforcing efforts and good performance, and validating progress leading towards the vision.

In contrast, the administrators and faculty members provided the lowest mean of 3.94 and 3.72, respectively on "creating ways to ensure that people's contributions were noted". It only goes to show that there were instances that school leaders failed to commend the outstanding accomplishments of the faculty members, whether small or big. This is in contrast to what Litz (2014) pointed out that school leaders must celebrate every milestone of their members. The importance of praise and recognition within a group cannot be overestimated. Good school leaders recognize and reward their members for their accomplishment by showing appreciation and giving praise for the work and contributions of the members. Positive feedback has a huge 
effect on motivation of teachers because it motivates them in their drive to transform the possible into reality.

Table 6. Comparison of perception on strategic leadership practices of school administrators.

\begin{tabular}{|c|c|c|c|c|c|c|c|c|c|}
\hline \multirow{2}{*}{$\begin{array}{l}\text { Strategic Leader- } \\
\text { ship Practices }\end{array}$} & \multirow{2}{*}{ Group } & \multicolumn{3}{|c|}{ Descriptives } & \multicolumn{2}{|c|}{ Levene's Test } & \multicolumn{2}{|c|}{ T-Test } & \multirow[b]{2}{*}{ Remarks } \\
\hline & & $\mathbf{N}$ & Mean & SD & $\mathbf{F}$ & Sig. & $\mathbf{t}$ & Sig. & \\
\hline \multirow{2}{*}{ Model the Way } & Administrator & 33 & 4.26 & .54 & 0.28 & 0.60 & 3.24 & 0.00 & Significant \\
\hline & Faculty & 207 & 3.93 & .55 & \multirow{3}{*}{0.10} & \multirow{3}{*}{0.75} & \multirow{3}{*}{3.45} & \multirow{3}{*}{0.00} & Reject Ho \\
\hline \multirow{4}{*}{$\begin{array}{l}\text { Inspire a Shared } \\
\text { Vision } \\
\text { Challenge the Pro- } \\
\text { cess }\end{array}$} & Administrator & 33 & 4.22 & .59 & & & & & Significant \\
\hline & Faculty & 207 & 3.86 & .56 & & & & & Reject Ho \\
\hline & Administrator & 33 & 4.12 & .59 & \multirow[t]{2}{*}{0.03} & \multirow[t]{2}{*}{0.87} & \multirow[t]{2}{*}{3.40} & \multirow[t]{2}{*}{0.00} & Significant \\
\hline & Faculty & 207 & 3.76 & .55 & & & & & Reject Ho \\
\hline Enable Others to & Administrator & 33 & 4.14 & .68 & \multirow[t]{2}{*}{0.30} & \multirow[t]{2}{*}{0.59} & \multirow[t]{2}{*}{2.90} & \multirow[t]{2}{*}{0.00} & Significant \\
\hline Act & Faculty & 207 & 3.83 & .56 & & & & & Reject Ho \\
\hline \multirow{2}{*}{ Encourage the Heart } & Administrator & 33 & 4.09 & .66 & \multirow[t]{2}{*}{0.46} & \multirow[t]{2}{*}{0.50} & \multirow[t]{2}{*}{2.40} & \multirow[t]{2}{*}{0.02} & Significant \\
\hline & Faculty & 207 & 3.81 & .62 & & & & & Reject Ho \\
\hline \multirow{2}{*}{ Overall } & Administrator & 33 & 4.16 & .56 & \multirow[t]{2}{*}{0.08} & \multirow[t]{2}{*}{0.78} & \multirow[t]{2}{*}{3.45} & \multirow[t]{2}{*}{0.00} & Significant \\
\hline & Faculty & 207 & 3.84 & .50 & & & & & Reject Ho \\
\hline
\end{tabular}

Table 6 compares the perception of faculty members and school administrators on the strategic leadership practices of school administrators using Independent Samples T-test. The Levene's test reflects the equality of variances of the group means being compared to ensure that the use of T-test is appropriate for comparison.

There is a significant difference in the overall perception of administrators and faculty members on the strategic leadership practices of school administrators as indicated by the significant absolute t-value of 3.45. The overall mean of administrators 4.16 with standard deviation of 0.56 is significantly higher compared to that of the faculty members with mean of 3.84 and standard deviation of 0.50 . Hence, the null hypothesis is rejected.

The data provides sufficient evidence to show that significant difference exists between faculty members and administrators with respect to their perceptions on the strategic leadership practices of school administrators. Nonetheless, both groups of respondents are satisfied with the administrators' strategic leadership practices. It is just that administrators have a higher regard with themselves with respect to their role as leaders. It supported the study of Litz (2014) who revealed that while the school administrators believed they were practicing high levels of transformational leadership, the majority of the teachers disagreed with that assessment. Likewise, it contradicted the study of Abu-Tineh (2009) who found out that there were no significant differences among the three experience level groups of teachers (new hiring, middle career, and long experience) in their perceptions of each dimension of Kouzes and Posner's model. This result of significant difference between perception of administrators and faculty members is true for each of the components of strategic leadership practices-Model the Way; Inspire a Shared Vision; Challenge the Process; Enable Others to Act and; Encourage the Heart. This is evident with the significant t-values shown in Table 6.

The findings implied that though differences in the perceptions existed between the school administrators and teachers, both were satisfied in the strategic leadership practices of school administrators. This means that the teachers and school administrators are satisfied by the way the latter lead the TEIs and infused strategic principles which make the leadership more dynamic and spreading. Hence, the findings may suggest that the school administrators have become a change leader by encouraging collaborative groups of teachers to take a role in the academic functions of the school. Herein, school administrators become proactively involved in fostering and promoting change by inspiring and encouraging the teachers. This has also reference to the study of Arslan (2011) who found out that institutions which adopted innovative management practices tend to have higher institutional performances.

The differences between the perceptions of the school administrators and teachers are minimal. This implied many salient 
points in the findings of the study. First, the school administrators were setting the examples in their efforts to promote innovation in the institution which according to Abu-Tineh et al. (2009), school leaders are the ones setting the example and building commitment through daily acts that create progress and momentum. Ideally, the foundation of a strong and sound strategic leadership is personal credibility which says a lot of positive things about the school leader. Both the teachers and school administrators realized that. Likewise, the findings suggested that both respondents believed that school administrators are passionate in making a difference in the TEI by envisioning a good profitable future for the organization, its personnel and the clients it served. Visioning is critical since one of the greatest barriers to school reform is the lack of a clear vision which shows that excellent schools have a clear vision whereas ineffective schools lack one (Matthews and Sammons, 2005). Moreover, school administrators are creating and recognizing new ideas and the teachers support these innovations which according to Senge (2006) manifest a healthy learning organization where people continually expand their capacity to create the results they truly desire and gather supports from the teachers.

Furthermore, the findings pointed out that the school administrators involve the teachers in planning the innovative programs while giving them the freedom of choice in the decision-making which is an act of enabling others which fosters collaboration and empowerment to all members (Abu-Tineh et al., 2009). In addition, it is evident that the teachers are encouraged and hence, motivated to partake and contribute in the attainment of the goals of innovation which is a representation that school leaders have a genuine heartfelt concern and care for people, an act of encouraging the heart according to Kouzes and Posner (2011). In general, both teachers and school administrators are united in stating that the latter's strategic leadership practices are instrumental in inspiring the former to also innovate and encouraged other to do so.

Consequently, DeLucia (2011) pointed out that collaboration is an important requirement in leadership should a leader enable others to act. When a school leader collaborates, he has to involve both internal and external stakeholders throughout the process, and make it possible for them to successfully implement the work required for success. What makes these involvements significant is that it provides the school personnel and stakeholders a sense of ownership of the school and its programs which inspire them to work at their highest capacity, skills and capabilities. In order to best accomplish this task, leaders foster collaboration and instill the components of teamwork, power, and trust across the organization. Effective school leaders are true to their words and translate such into actions by way of open discussion of plans and programs among the members of the academic community.

The findings implied that school administrators who can enable people are instrumental in shaping a vision of academic success for all students, one based on high standards and creating a climate hospitable to education in order that safety, a cooperative spirit, and other foundations of fruitful interaction prevail. As such, school administrators must cultivate leadership in others so that teachers and other adults assume their part in realizing the school vision. Effective strategic leadership begins with the development of an innovative vision which is deeply rooted in the academic and social learning goals of the schools and of commitment to high standards and the success of all members of the academe. The school administrators help to spell out that vision and get all others on board with it.

On the other hand, the strategic leadership practices of the school administrators in terms of Encourage the Heart was found to have a moderately high correlation with their innovative management style along innovative vision and strategy (.69), resources (.68) and organizational structure (.68). This is another interesting combination of strategic leadership practices and innovative management style which are being looked into among school administrators.

\section{Summary of Findings}

Nine State Universities were selected to serve as research locale. These schools were chosen because of the number of years in existence of these TEIs in universities and colleges in Region 3. Selected faculty members, deans and unit heads were selected 
as respondents of the study. In choosing the respondents purposive sampling technique was used.

Weighted mean was utilized to find out the strategic leadership practices of school administrators as well as their innovative management as perceived by faculty members and themselves. Independent Samples T-test was used to determine if there was any significant difference in the perceptions of school administrators and their subordinates regarding the formers' strategic leadership practices and innovative style of management. Levene's test was employed prior to conducting T-test to ensure that the assumption of equality of variances is met and erroneous results are avoided.

Further, Independent Samples T-test was used to relate profile variables such as civil status and specialization with the innovative management of school administrators.

Based on the data gathered in the study, the following were the findings:

1) On the strategic leadership practices of school administrators.

The strategic leadership practices of school administrators in terms of Model the Way, Inspire a Shared Vision, Challenge the Process, Enable Others to Act and Encourage the Heart were perceived by themselves and the teachers as satisfactory.

2) On the innovative management of school administrators.

The innovative management of school administrators in terms of innovative vision and strategy, resources, organization structure and culture and climate were perceived by themselves and the teachers as satisfactory. On the other hand, the innovative management of school administrators in terms of innovation process was perceived by themselves as satisfactory and by teachers as good.

3) On the significant difference in the perceptions of school administrators and their subordinates regarding the formers' strategic leadership practices.

There was significant difference between the perception of faculty members and school administrators on the strategic leadership practices of school administrators.

\section{Conclusion and Recommendations}

There is no significant difference in the perceptions of school administrators and their subordinates regarding the formers' strategic leadership practices.

Based on the conclusions drawn, the following are hereby recommended:

1) The Strategic leadership practices may be further improved thru initiating activities which can influence both school heads and faculty since the perception of the administration falls on the satisfactory level only. Likewise, school administrators need to upgrade their strategic leadership practice by continuing professional growth and see to it that learnings are applied in order to elevate the perception of teachers about the administrators' leadership practices to the innovative process highest possible level since teachers' perception falls on the satisfactory level only.

2) Further study is recommended on the effect of teacher's perception of the school administrator's strategic leader practices to the administrative performance of the deans of the college of education, whether it influences their actual performance or influences their perception of themselves as school leaders.

3) School administrators may capitalize on enabling others to act since it has been found out that it is the best predictor of overall innovative management of school administrators.

\section{References}

Marzano, R., Waters, T., \& McNulty, B. (2005). School Leadership that Works from Research to Results. Aurora: McREL.

Kouzes, J. M., \& Posner, B. Z. (2011). The Five Practices of Exemplary Leadership: Government. San Francisco, CA: Pfeiffer.

Lazaro, G. J. (2009). Correlation of Performance and Leadership Practices towards a Teacher Leadership Enhancement Program. (Institutional Research, Southville International School and Colleges, Las Pinas City, Manila, 2009). 
Abu-Tineh, A. M. (2009). Kouzes and Posner's Transformational Leadership Model in Practice: The Case of Jordanian Schools. Journal of Leadership Education, 7(3):45-66.

Northouse, P. G. (2010). Leadership: Theory and Practice. Thousand Oaks: Sage.

Watthews, P., \& Sammons, P. (2005).Survival of the Weakest: The Differential Improvement of School Causing Concern in England. London Review of Education, 3(2), 159-176.

DeLucia, J. M. (2011). Barriers and Supports to Implementation of Principal Leadership for School Change. (Unpublished Dissertation, Walden University).

Senge, P. M. (2006). The Fifth Discipline. New York, NY: Doubleday.

Dalton, M. (2005). Personal Best Leadership Stories of Educational Administration Students. National Forum of Educational Administration, $20 \mathrm{E}(4), 3-9$.

Saban, J., \& Wolfe, S. (2009). Mentoring Principals around Leadership Practices. Catalyst for Change, 36 (1), 2-6.

Kouzes, J. M., \& Posner, B. Z. (2011). The Five Practices of Exemplary Leadership: Government. San Francisco, CA: Pfeiffer.

Arslan, A. (2011). Innovative Management Practices and Their Impact on Local E-government Performance: The Turkish Provincial Municipalities. African Journal of Business Management, 5(24): 10190-10197. 